\title{
PERANCANGAN IKLAN LAYANAN MASYARAKAT SAVE KENDENG
}

\author{
John $^{1}$, Sony Sirait ${ }^{2}$ \\ 1,2 Program Studi Desain Komunikasi Visual Fakultas Seni dan Desain \\ Universitas Potensi Utama \\ 1john_tang01@ymail.com, ${ }^{2}$ sony.sirait21@gmail.com
}

\begin{abstract}
ABSTRAK
Air bersih adalah sumber kehidupan yang paling utama bagi makhluk hidup, namun hal ini yang mulai terasa asing di daerah Gunung Kendeng. Pegunungan Kendeng merupakan daerah pegunungan kapur yang membentang di bagian utara Pulau Jawa, tepatnya di Kabupaten Pati, Jawa Tengah. Pegunungan kendeng yang kaya akan kapur dijadikan sumber penambangan utama bagi industri semen. Pegunungan Kendeng juga kaya akan mineral air yang menetes melalui stlaktit, turun ke sungai dan dimanfaatkan masyarakat utuk irigasi sawah, minum, mandi, dan sebagainya. Namun hal ini terasa semakin sulit karena kian berkembangnya industri penambangan di sekitar Gunung Kendeng, sehingga sumber mata air utama di daerah tersebut nyaris hilang. Penelitian ini menggunakan metode penelitian kuantitatif untuk mencari seberapa peduli masyarakat terhadap kelangsungan hidup di daerah pegunungan Kendeng. Hasil dari penelitian berupa Iklan Layanan Masyarakat yang akan ditampilkan di media sosial.
\end{abstract}

Kata kunci : ILM, Jawa tengah, Kendeng, Kuantitatif, Media Sosial

\begin{abstract}
Clean water is the most important source of life for living things, but this is beginning to feel strange in the area of Mount Kendeng. Kendeng Mountains are limestone mountainous areas stretching across the northern part of Java Island, precisely in Pati Regency, Central Java. Kendeng mountains which are rich in lime are the main mining source for the cement industry. The Kendeng Mountains are also rich in mineral water that drips through stylacts, goes down into the river and is used by the community to irrigate rice fields, drink, bath, and so on. But this feels increasingly difficult because of the growing development of the mining industry around Kendeng Mountain, so that the main spring sources in the area are almost gone. This research uses quantitative research methods to find out how much people care about the survival of the Kendeng mountain region. The results of the research in the form of Social Campaign will be displayed on social media.
\end{abstract}

Keywords: Central Java, Kendeng, Quantitative, Social campaign, Social Media,

\section{PENDAHULUAN}

Salah satu fitrah kita sebagai manusia adalah menjaga alam, bersahabat dengan alam, melindungi alam. Karena kita sangat membutuhkan alam. Kita bernafas menggunakan oksigen dari pepohonan, air yang keluar dari bumi, sampai rumah tempat kita tinggal bergantung dengan alam. Dan jika alam diusik haruslah kita membela. Karena dapat menganggu keberlangsungan hidup kita sebagai manusia.

Dalam pasal 6 ayat 1 UU nomor 23 tahun 1997 dikatakan Setiap orang berkewajiban memelihara kelestarian fungsi lingkungan hidup serta mencegah dan menanggulangi pencemaran dan perusakan. Jadi telah jelas kewajiban kita untuk menjaga lingkungan. Salah satu konflik agraria yang dapat mengancam lingkungan adalah pembangunan pabrik semen di kawasan gunung Kendeng, kabupaten Rembang. Peristiwa persengketaan ini bermula di 
tahun 2010, dan terus berlanjut hingga sekarang karena belum menemui titik penyelesaian. Adapun pihak-pihak yang berseteru antara lain JMPPK (Jaringan Masyarakat Peduli Pegunungan Kendeng) dan PT Indocement Tunggal Prakarsa Tbk. yang dalam hal ini lewat anak perusahaannya yang membangun pabriknya yaitu, PT Sahabat Mulia Sakti (SMS).

Ada 3 kecamatan yang akan menjadi lahan pembangunan pabrik semen, dan semuanya telah menjadi petani bertahun-tahun. Tentu mereka akan kehilangan pekerjan. Ditambah lagi daerah yang digunakan adalah daerah resapan air. Ada banyak warga disekitar pegunungan kendeng yang bergantung dengan mata air tersebut. Dengan dalih mengejar kebutuhan semen Indonesia pabrik itu dibangun diatas lahan yang lebih dibutuhkan untuk masyarakat menanam padi.

Berdasarkan situs Tempo edisi Selasa,15 September 2015, AMDAL (Analisis Mengenai Dampak Lingkungan) dinilai mencurigakan dikarenakan banyaknya data yang tidak tepat dilapangan. Mengingat banyaknya kejanggalan sudahlah barang tentu kita khawatir terhadap pembangunan pabrik semen yang terus berjalan ini.

\section{I.1. Defenisi Desain Komunikasi Visual (DKV)}

Asal mula kata desain adalah dari bahasa latin yakni designare, dalam terjemahan Bahasa Inggris yang berarti design artinya menggambar, merancang. Desain sinonim dengan merancang. Merancang adalah tahapan penciptaan suatu bentuk atau rupa untuk maksud tertentu. (Wong, 1986:1)

Komunikasi (communications) bermula dari bahasa Latin yang bersumber dari kata communis yang artinya sama, arti dari kata sama di sini adalah sama makna. Jadi dalam jika dua orang atau lebih yang terlibat dalam komunikasi, misalnya dalam percakapan maka komunikasi telah terjadi selama ada kesamaan (saling mengerti) mengenai makna yang diperbincangkan.

Defenisi visual adalah semua yang bisa dilihat serta dapat digunakan untuk menyampaikan makna/arti, ataupun pesan yang kemudian direspon indera penglihatan. Visual juga didefenisikan suatu bahasa yang ditangkap panca indera terutama mata, yang bias kita ditafsirkan dari apa yang dilihat dan kemudian dicernanya secara langsung terutama oleh mata.

Mata sebagai indera utama dalam komunikasi visual. Komunikasi visual yang sangat dominan menggunakan bahasa visual (kekuatan utama dalam desain visual penyampaian pesan) sebagai penyampai arti, makna, informasi, dan pesan.(Kusrianto, 2007:10).

Jadi dapat disimpulkan DKV merupakan salah satu disiplin ilmu yang mempelajari konsep komunikasi serta ungkapan desain kreatif melalui media-media aplikasi dalam penyampaian pesan dan ide/gagasan melalui visual dengan cara mengelola semua elemen grafis dalam bentuk/gambar, warna, dan komunikasi huruf serta tata letak atau perwajahan (layout) sehingga pesan yang ingin disampaikan ke target audience dapat tersampaikan (Kusrianto, 2007:2). DKV merupakan aplikasi penerapan dari kreatifitas seni serta komunikasi dalam kebutuhan dunia bisnis dan industri pada masa sekarang ini dalam mempromosikan produknya.

Bogusky (2009:23) berpendapat DKV merupakan salah satu ilmu terapan yang diturunkan dari seni rupa, komunikasi yang disampaikan berupa simbol/tanda-tanda dan memiliki arti/makna dari hasil karya yang ditampilkan secara visual . Komunikasi yang 
dilakukan melalui visual lebih memfokuskan terhadap pengembangan bentuk gambar, lambing serta tanda-tanda yang dapat dilihat oleh target audience lewat indera penglihatan sebagai Bahasa penyampai pesan untuk berkomunikasi. DKV mempelajari cara mengkonsep komunikasi melalui ungkapan kreatif, teknik, media, serta elemen desain grafis dalam bentuk gambar, warna dan huruf, termasuk layoutnya, sehingga pesan serta ide yang ingin disampaikan bisa diterima oleh target audiencenya.

\section{I.2. Communication Media/Media Komunikasi}

Media merupakan alat/sarana yang dipergunakan dalam penyampaian pesan dari komunikator kepada masyarakat luas. Para ahli psikologi berpendapat dalam komunikasi sesame manusia, maka media yang dominan untuk berkomunikasi ialah indera manusia seperti telinga dan mata. Pesan yang diterima telinga dan mata selanjutnya akan diproses oleh pikiran orang yang menerimanya untuk mengontrol dan menentukan sikapnya dari pesan yang dilihat atau didengar untuk melakukan tindakan respon dari pesan tersebut (Cangara, 2006:119).

Media komunikasi merupakan alat perantara yang digunakan sebagai komunikator dalam penyampaian pesan sehingga sampai ke orang yang dituju. Jadi, elemen utama media komunikasi yaitu penggunaan serta pemilihan alat yang diinginkan sebagai perantara yang dilakukan oleh komunikator dengan sengaja. Sehingga dalam hal ini media komunikasi lebih tertuju terhadap penggunaan serta pemilihan media komunikasi yang digunkan (Vardiansyah, 2004:24).

Dari pengertian diatas, dapat diartikan media komunikasi adalah suatu alat yang digunakan untuk menyampaikan pesan-pesan kreatif dari konsep yang telah didesain secara grafis untuk mempermudah pesan diterima oleh orang-orang yang melihatnya atau target audience.

\section{STUDI LITERATUR}

II.1.Penelitian tentang Strategi Perancangan Poster Pada Iklan Layanan Masyarakat Kampanye Menabung Air di Yogyakarta

Penelitian Danu W., diterbitkan oleh STSRD VISI Bandung pada Jurnal Kreatif Vol 3, No 1 pada tahun 2015. Rumusan masalah ini adalah bagaimana konsep strategi perancangan poster yang efektif dan menarik untuk menarik minat dan rasa kepedulian masyarakat terhadap pelestarian cadangan air tanah di Yogyakarta?.

II.2.Penelitian tentang Perancangan Iklan Layanan Masyarakat Kampanye Pemeriksaan Kesehatan dan Pengobatan Dini

Penelitian Karina Tiffany P., et al. yang diterbitkan oleh Universitas Kristen Petra Siwalankerto, Surabaya dalam Jurnal DKV Adiwarna Vol 1, No 2 Tahun 2013. Rumusan masalah penelitian tersebut adalah ingin membangkitkan kesadaran pada masyarakat pada umumnya dan remaja pada khususnya untuk dapat melakukan pemeriksaan kesehatan sedini mungkin. Hal ini bertujuan untuk dapat mengetahui apakah ada penyakit di dalam tubuh orang tersebut, jika ada dapat dilakukan penangan dengan sedini mungkin. Melalui kampanye ini pengkarya mngharapkan tingkat kesehatan di masyarakat semakin meningkat. 


\section{II.3.Kampanye Sosial Penanggulangan Sampah Plastik di Kabupaten Bekasi Timur}

Penelitian karya Eka Ari Setyawan yang diterbitkan Fakultas Ilmu Komunikasi Program Studi Desain Komunikasi Visual, Universitas Persada Indonesia Y.A.I, Jakarta pada Jurnal Komposisi Vol 1, No 2 pada tahun 2014. Melalui penelitiannya Eka membahas mengenai bagaimana melakukan kampanye social agar ibu rumah tangga terpengaruh untuk mengurangi pemakaian bahan plastic sebagai kebutuhan sehari-hari, kemudian bagaimana menuangkannya dalam visualisasi untuk desain kampanye social tersebut.

\section{II.4.Penelitian Perancangan ILM dan Kampanye Pelestarian Bangunan Tua Kota Solo melalui DKV}

Penelitian karya Adi Satria Mahardika pada tahun 2011 di dalam laporan tugas akhirnya untuk memperoleh gelar kesarjanaan di Universitas Sebelas Maret Surakarta Fakultas Sastra dan Seni Rupa Program Studi Desain Komunikasi Visual. Pada karya Adi Satria Mahardika membahas mengenai permasalahan dalam perancangan Iklan Layanan Masyarakat sebagai sarana pelestarian bangunan tua di kota Solo dan bentuk kontribusi apa saja dalam DKV yang dapat digunakan dalam perancangan ILM pelestarian bangunan tua di kota Solo tersebut.

\section{III.PEMBAHASAN}

Berbagai permasalahan yang dihadapi di berbagai daerah haruslah memiliki solusi dan penanggulangannya. Beberapa masalah dapat terselesaikan secara langsung dimana masalah itu terjadi, namun terkadang ada masalah yang memerlukan waktu dan dukungan dari berbagai elemen masyarakat bahkan sampai dengan organisasi tertentu. Salah satu permasalahn yang memerlukan dukungan dan perhatian tersebut adalah menyelamatkan Pegunungan Kendeng dari pengerusakan oleh oknum-oknum yang tidak perduli terhadap Lingkungan

Penelitian ini merupakan salah satu solusi untuk menyelamatkan Pegunungan Kendeng, walaupun tidak dapat menjamin. Oleh karena itu diharapkan melalui kampanye sosial ini seluruh lapisan masyarakat, maupun lembaga dapat ikut menyuarakan kesengsaraan mayarakat yang berada di sekitar pegunungan Kendeng. Kampanye sosial ini nantinya akan lebih digiatkan dan disebarkan melalui media sosial karena media sosial saat ini adalah alat komunikasi yang sangat ampuh dan pesat untuk mempromosikan atau mnyebarkan berita. Media sosial juga dapat menembus lapisan masyarakat karena hamper seluruh masyarakat memiliki sosial media. Perancangan ILM ini tidak terlepas dari unsur-unsur seni rupa juga memperhatikan fungsi-fungsi dasar dari desain komunikasi visual.

\section{III.1.Prinsip-prinsip dan Fungsi Dasar Desain Komunikasi Visual (DKV)}

\section{III.1.1.Prinsip-prinisp DKV}

Prinsip-prinsip DKV berguna sebagai dasar untuk melakukan penilaian terhadap desain alternatif yang ditawarkan dalam menentukan desain terbaik, prinsip-prinsip tersebut diantaranya: 


\section{Balance/Keseimbangan}

Keseimbangan adalah prinsip di dalam desain yang menghindari tampilan tidak seimbang terhadap bidang tertentu ataupun sisi ruang yang diletakkan unsur-unsur rupa di dalamnya (Kusrianto, 2007:38).

\section{Focal Point/Titik Fokus}

Titik fokus merupakan bagian yang menjadi pusat perhatian, bagian yang sangat diperlukan pada komposisi desain untuk menonjolkan bagian tersebut menjadi sesuatu yang penting serta dijadikan objek visual yang utama (Kusrianto, 2007:42).

\section{Visual hierarchy/Hirarki Visual}

Hirarki visual merupakan prinsip untuk mengatur semua elemen terhadap perhatian visual serta tingkatan desain lain yang langsung berhubungan terhadap titik fokus(Suyanto, 2004:64).

\section{Rhythm/Ritme}

Ritme dapat dikatakan pola yang didesain dengan cara membuat ataupun mengulang variasi desain melalui pertimbangan terhadap ruang yang tersedia serta dengan merancang perasaan berpindah dari satu elemen ke elemen lain baik mealui warna, ukuran maupun nilai yang ditampilkan secara bersamaan terhadap pengulangan-pengulangan tersebut (Pujirianto, 2005:94).

\section{Unity/Kesatuan}

Kesatuan adalah prinsip ysng bertolak terhadap keselasaran dari semua unsur yang didesain dari segi wujudnya ataupun hubungannya terhadap ide yang melandasinya. Kesatuan diperlukan dalam suatu karya grafis untuk saling mendukung anatar satu elemen dengan elemen yang lain sehingga didapat fokus yang diinginkan (Kusrianto, 2007:35).

\section{Kesesuaian/ Proporsi}

Proporsi dapat dinyatakan sebagai perbandingan antara objek yang satu terhadap objek yang lain. Proporsi bukanlah skala, namun proporsi erat kaitannya terhadap objek yang lain yang dapat disesuaikan dengan objek-objek yang telah ada sebelumnya. Misalnya ukuran desain gambar yang sesuai untuk newsletter jelas tidak proposional untuk ukuran baliho (Pujirianto, 2005:94).

\section{Sederhana}

Prinsip sederhana dapat dimasukkan dalam desain visual dalam artian jika menambah objek lain akan menjadi kacau dalam desain tersebut namun terkadang jika mengurangi objek desain seperti ada yang kurang atau hilang dalam desain tersebut. Sederhana bukan harus sedikit, namun dapat diartikan pas yang berarti tidak lebih atau tidak kurang, istilah yang tepat adalah proposional (Sanyoto, 2005:209).

\section{Perbedaan/Kontras}

Dalam sebuah desain kontras sangat dibutuhkan untuk menimbulkan kesan yang tidak monoton sehingga memungkinkan adanya kontras dalam setiap komposisi desain. Kontras 
sebaiknya dimunculkan seperlunya saja karena jika berlebihan akan dapat memunculkan ketidakteraturan /kontradiksi sehingga tidak memunculkan harmonisasi desain (Pujirianto, 2005:94).

\section{III.1.2.Fungsi Dasar Desain Komunikasi Visual (DKV)}

Di dalam buku yang ditulis oleh Cenadi (1994:4) "Elemen-elemen Desain Komunikasi Visual), DKV memiliki beberapa fungsi dasar sebagai berikut:

\section{DKV sebagai Media Identifikasi}

Fungsi yang utama dari ilmu DKV yakni untuk mengidentifikasi. Data identitas diri orang bisa menjelaskan tentang siapa dia, atau asal usul orang tersebut dari mana. Hal ini juga digunakan untuk mengidentifikasi benda, institusi/organisasi ataupun produk, karena dengan memiliki identitas maka seseorang bisa menggambarkan mutu dari produk/jasa ataupun barang serta institusi sehingga dapat dikenali, dari sisi produsen ataupun dari sisi konsumen.

Pembeli lebih mudah mengatakan beli barang merk A dari pada hanya menyebutkan nama bendanya saja, hal tersebut dapat dikarenakan apakah merk A itu logonya bagus serta menggambarkan produknya.

\section{DKV merupakan Media Informasi dan Petunjuk /Instruksi}

Fungsi DKV untuk memberikan informasi dan petunjuk memiliki tujuan untuk menjelaskan kaitan sesuatu satu hal kepada hal lainnya dengan satu atau beberapa petunjuk, posisi, ukuran dan arah, misalnya kurva, simbol, diagram, petunjuk arah dan peta. Informasi yang disampaikan kepada orang yang tepat akan menjadi berguna, pada tempat dan waktu yang tepat, dipresentasikan dalam bentuk tampilan yang logis serta dimengerti sipenerima informasi.

Tanda atau simbol dapat menjadi media informasi dapat dilihat dan digunakan misalnya melihat toilet dengan simbol kumis yang berarti toilet diperuntukkan untuk pria dan toilet dengan simbol lipstik yang berarti toilet diperuntukkan untuk wanita.

\section{DKV untuk Media Promosi dan Publikasi}

DKV sendiri juga digunakan untuk media promosi atau bisa juga publikasi, maksudnya dalam menyampaikan pesan, menjadikan atensi terhadap pesan yang divisualkan serta menyampaikan pesan itu untuk sampai ke penerimanya. Agar pesan yang ingin disampaikan sampai ke target audience, maka gambar serta pemilihan kata yang digunakan bersifat persuasif dan menarik, hal tersebut dikarenakan target akhir ditujukan untuk menjual produk atau jasa.

Contoh Iklan yang dipasang di videotrone biasanya untuk mempromosikan suatu produk atau publikasi mengenai suatu acara yang didukung oleh produk tertentu, penggunaan videotrone termasuk strategi untuk mengundang atensi atau perhatian agar pesan serta promosi yang ingin disampaikan tercapai sampai ke target audience yang diinginkan. Poster juga sangat banyak digunakan sebagai media publikasi misalnya utuk Iklan Layanan Masyarakat sangta efektif digunakan karena penempatan yang fleksible dapat dengan mudah langsung menuju target audience terlebih di tempat-tempat umum yang banyak digunakan orang banyak. 


\section{III.2.Iklan Layanan Masyarakat (ILM)}

Kasali (1993: 201) menyatkan Iklan Layanan Masyarakat merupakan pengumuman yang bertujuan tidak mengambil keuntungan materi serta mempromosikan progamprogam, kegiatan ataupun pelayanan yang dilakukan pemerintah pusat/local. Kegiatan ini juga dapat dilakukan oleh organisasi sosial atau lembaga kemasyarakatan dalam melakukan pengumuman-pengumuman lain yang bersifat sosial, dikenal sebagai pelayanan masyarakat.

Di dalam Kamus Bahasa Indonesia, ILM yang termasuk periklanan Indonesia adalah salah satu periklanan yang dirancang oleh pemerintah, suatu perusahaan komersial ataupun nonkomersial dalam mencapai tujuan sosial masyarakat dengan sasaran utama untuk mensejahterakan masyarakat.

Melalaui ILM masyarakat dapat diajak berkomunikasi untuk memikirkan sesuatu hal yang bermanfaat dalam memunculkan kesadaran diri yang bersumber dari nurani individual ataupun kelompok. Hal-hal yang bermanfaat untuk dikomunikasikan berorintasi ada sosial masyarakat, lingkungan hidup, serta kebudayaan.

ILM memiliki tujuan untuk melayani unsur kepentingan sosial dan masyarakat tanpa mengharap imbalan. Untuk tujuan itu ILM harus memenuhi kriteria-kriteria yang mendasarinya, menurut Dewan Periklanan Amerika Serikat (Ad Council ), kriteria-kriteria dasar tersebut yakni :

1. Nonkomersial (tidak ada imbalan komersial)

2. Tidak menyinggung agama

3. Nonpolitik (tidak ada unsur politisasi)

4. Berpengetahuan Nasional ( berwawasan demi bangsa dan negara)

5. Ditujukan untuk seluruh elemen masyarakat

6. Diajukan oleh organisasi yang telah diakui atau diterima

7. Dapat dipublikasikan/diiklankan

8. Memiliki dampak sosial serta kepentingan umum yang tinggi sehingga dapat memperoleh dukungan dari masyarakat, media lokal maupun nasional.

\section{III.3.Media Sosial (Social Media)}

Kotler dan Keller berpendapat Media sosial merupakan wadah bagi konsumen untuk mendapatkan segala informasi teks, video, gambar, serta audio dengan antar satu dengan yang lain. Media sosial saat ini merupakan sarana informasi yang paling cepat menyebar dan mendapat respon yang tinggi dari para penggunanya, oleh karena itu sangat efektif membuat kampanye sosial dengan memanfaatkan media sosial.

Oleh karena itu, Kampanye sosial ini sangat tepat jika dipublikasikan melalui media sosial. Melalui media sosial diharapkan dapat terus melakukan share dan mendukung pengembalian pegunungan Kendeng sebagaimana mestinya, sehingga masyarakat dapat hidup layak seperti sebelumnya. Media sosial juga dijadikan ujung tombak untuk dukungan masyarakat Kendeng untuk memperoleh hak-hak mereka, serta diharapkan dapat tanggapan dan simpati dari pemilik kekuasaan di negara Indonseia ini. 


\section{III.4.Tipografi}

Tipografi di dalam bidang desain komunikasi visual dapat dinyatakan bahasa langsung terlihat, sedikit berbeda dengan simbol atau tanda yang menggambarkan sesuatu makna. Tipografi merupakan sarana dalam menguraikan kata-kata yang diucapkan ke pesan halaman yang disampaikan ke audience untuk dibaca. Peranan tipografi tidak lain untuk mengkomunikasikan informasi serta ide dari simbol atau tanda tertentu ke pengamat. Secara tidak sadar manusia selalu berhubungan dengan tipografi setiap saat.

Keunikan tipografi juga bisa dilihat dari persepsi dari pembuat atau otrang yang melihat, misalnya $\mathrm{O}$ dapat diartikan huruf $\mathrm{O}$ namun juga dapat diartikan lingkaran. Oleh karena itu tipografi sangat berpengaruh dalam perancangan logo, dalam hal ini penulis juga melihat tipografi yang unik dari logo Rumah Makan Patinku yang menggunakan jenis font Cosmic Sans Ms.

Kusrianto menjelaskan tipografi adalah suatu bidang ilmu yang membahas dan mempelajari dasar-dasar serta jenis-jenis huruf. Tipografi mempunyai dua fungsi, yakni tipografi sebagai fungsi estetis, tipografi dapat digunakan untuk mendukung penampilan pesan yang igin disampaikan agar tampak menarik dan fungsi komunikasi, dan Tipografi sebagai fungsi komunikasi, tipografi digunakan dalam penyampaian pesan (informasi) dalam bentuk teks dengan tepat dan jelas. (Kusrianto,2007:76)

Tipografi juga menjadi elemen penting dalam perancangan desain visual ILM di mana tipografi yang digunakan dalam desain tersebut memiliki makna tersendiri, begitu juga dengan letaknya. Tipografi menyampaikan pesan secara langsung tidak seperti simbol atau tanda dalam desain komunikasi visual yang memiliki makna tersirat untuk mengartikannya.

\begin{tabular}{|c|c|c|}
\hline HEADLINE & JENIS HURUF & STATUS \\
\hline SEMEN TIDAK BISA DIMINUM & Arial & $\bar{r}$ \\
\hline SEMEN TIDAK BISA DIMINUM & $\begin{array}{l}\text { Tw Cen MT Condensed } \\
\text { Ekstren Bold }\end{array}$ & $\mathrm{x}$ \\
\hline SEMEN TIDAK BISA DIMINUM & $\begin{array}{l}\text { PERPETUA TITUNG } \\
\text { MT }\end{array}$ & $\mathrm{x}$ \\
\hline SEMEN TIDAK ELSA DIMIIIUM & $\mathrm{CH}$ er & $x$ \\
\hline SEMEN TIDAK BISA DIMINUM & Viker Hand ITC & $\mathrm{x}$ \\
\hline
\end{tabular}

\section{Gambar 1. Alternatif jenis Tipografi yang digunakan dalam visualisasi Kampanye Sosial}

\section{III.4.Warna}

Pada hakikatnya warna merupakan suatu kualitas cahaya yang dipantulkan dari suatu objek ke mata manusia yang melihat objek tersebut. Pantulan yang dihasilkan membentuk kerucut-kerucut warna di dalam retina, yang memungkinkan munculnya gejala warna terhadap objek benda yang dilihat sehingga bisa merubah respon manusia tersebut. Warna dapat menjadi subjektifitas bagi orang yang melihatnya atau bagi orang yang menggunakan warna tersebut, karena representasi makna warna yang luas tergantung individu yang menafsirkan warna tersebut. Warna erat kaitannya dengan logo, karena warna adalah unsur elemen penting dalam posisi sebagai pengingat dan identitas dari logo. Warna juga merupakan unsur penting dalam merespon kepekaan indera penglihatan agar dapat 
mempengaruhi rasa, perhatian, reaksi, dan keinginan seseorang yang melihatnya. (Kusrianto, 2007:46).

Warna memiliki peranan penting dalam desain komunikasi visual, karena warna memliki efek psikologis bagi manusia atau makhluk hidup yang melihatnya. Warna juga memiliki kesan yang disesuaikan dengan aneka warna tersebut untuk menyentuh perasaan bagi penikmatnya. Warna juga dijadikan sebagai media pengingat, karena melalui warna manusia lebih cepat mempersepsikan sesuatu hal ke alam bawah sadar akan sesuatu hal yang pernah dilihatnya, seperti melihat warna merah yang identik dengan rasa semangat, panas ataupun emosi, warna hijau dapat dipersepsikan dengan sayuran, ketenangan, ataupun keindahan, serta warna-warna yang lain.

Ada beberapa warna yang digunakan dalam perancangan visualisasi kampanye sosial Save Kendeng ini sebagai berikut :

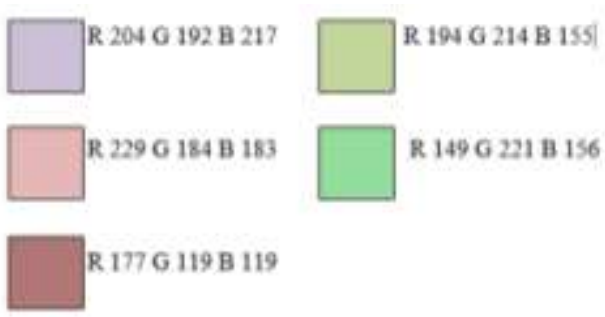

Gambar 2. Alternatif warna yang digunakan dalam visualisasi Kampanye Sosial

III.5.Metode Penelitian

Berdasarkan data dan informasi yang telah diperoleh, maka agar tahapan dan proses perancangan kampanye sosial Save Kendeng ini lebih mudah dan sistematis maka diperlukan penyusunan metode, strategi, struktrur dalam perancangan yang akan digarap.

\section{III.5.1.Ruang Lingkup Perancangan}

Berdasarkan situs Tempo edisi Selasa,15 September 2015, AMDAL (Analisis Mengenai Dampak Lingkungan) dinilai mencurigakan dikarenakan banyaknya data yang tidak tepat dilapangan. Mengingat banyaknya kejanggalan sudahlah barang tentu kita khawatir terhadap pembangunan pabrik semen yang terus berjalan ini. 


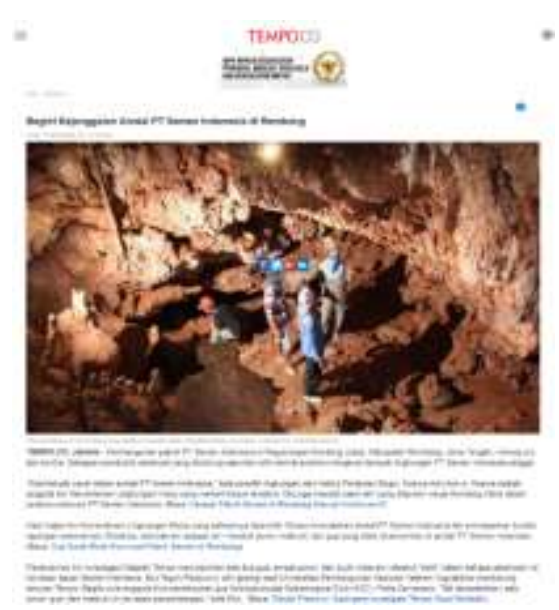

\section{Gambar 3. Berita dari situs Tempo mengenai pelanggaran AMDAL Sumber: Situs TEMPO.CO}

III.5.2. Segmentasi yang dituju dari Iklan Layanan Masyarakat ini.

Adapun target yang dituju tersebut dengan segmentasi sebagai berikut :

1.Demografi

Usia $\quad: 15-50$ tahun (target audience)

Jenis Kelamin : Laki-laki dan perempuan

Kelas Sosial : Pelajar, Mahasiswa, Pejabat, Aktivis Lingkungan

\section{Geografi}

Lokasi sasaran yang dituju adalah seluruh wilayah Indonesia yang terjangkau media sosial

\section{Psikografis}

Secara psikografi, target aundience yang dituju adalah pengguna Media sosial

\section{Behaviour (Perilaku)}

Dari segi behaviour (perilaku) semakin meningkat pengguna sosial media yang melakukan share kepedulian ini maka tingkat kampanye sosial ini berhasil.

\section{III.5.3.Metode Pengumpulan Data}

\section{III.5.3.1. Data Visual melalui website}

Karena keterbatasan dana dan waktu peneliti mencari data visual ditunjang dari gambargambar yang ada di website dan media sosial. Pengambilan data visual di website bertujuan untuk mempermudah data-data yang sulit untuk di dokumentasikan sendiri serta untuk memenuhi kebutuhan bentuk visual pada perancangan yang tidak diperboleh dari dokumentasi sendiri. 


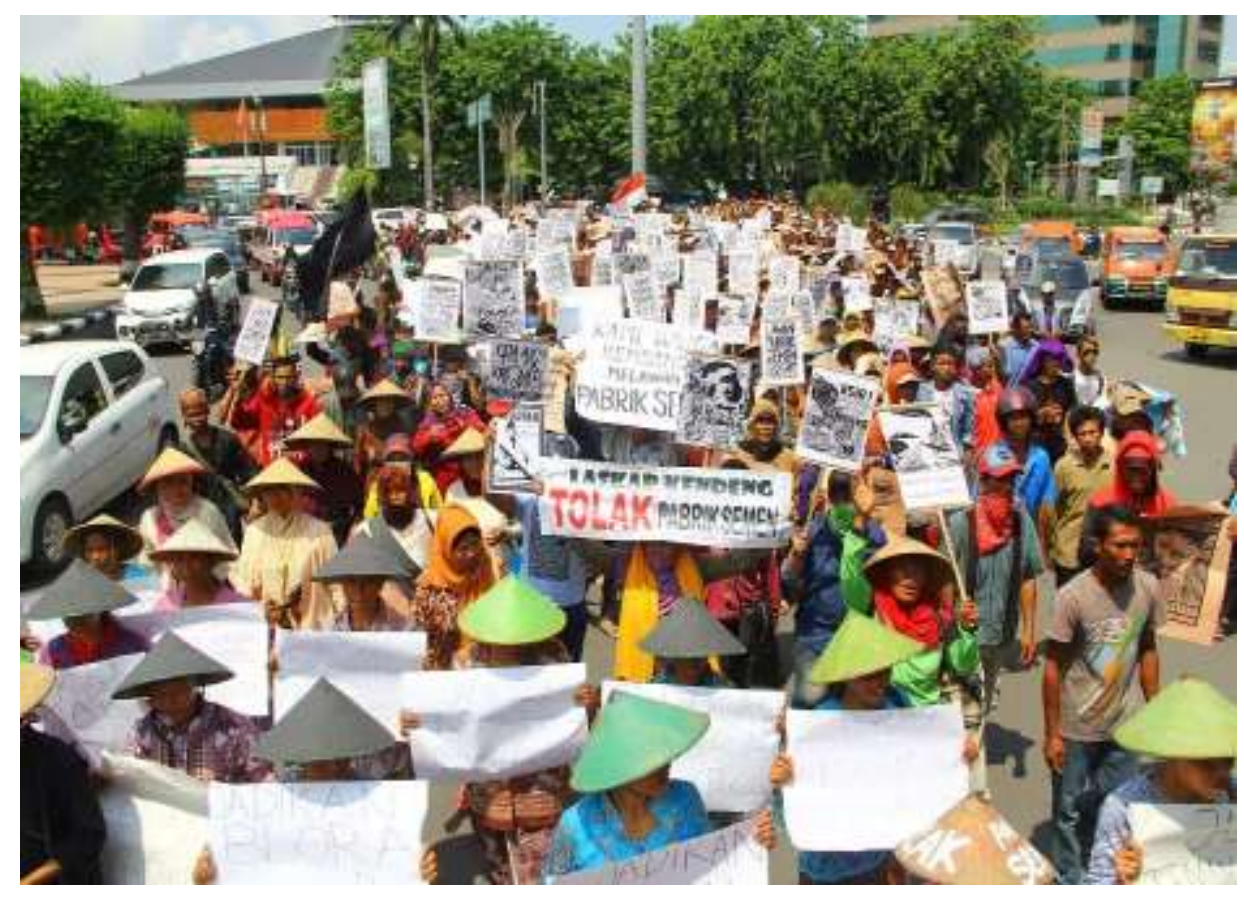

Gambar 4. Penolakan Masyarakat sekitar Pegunungan Kendeng terhadap Pembangunan Pabrik semen

Sumber: http://koranbumen.blogspot.com/2014/

III.5.3.2. Data Verbal melakukan wawancara di sekitar tempat tinggal peneliti

Peneliti juga melakukan wawancara dengan bertanya kepada beberapa sumber, yaitu orang-orang yang ada di sekitar peneliti, yang dapat memberikan informasi untuk melengkapi data dalam perancangan ini seperti: dosen-dosen Fak. Seni dan Desain dan dosen-dosen Fak. Hukum di Univ. Potensi Utama. Metode wawancara yang akan dilakukan adalah metode wawancara terstruktur (Structured Interview) dan wawancara tidak terstruktur (Unstructured Interview) merupakan wawancara yang dilaksanakan secara terencana dengan pedoman pada daftar pertanyaan yang telah dipersiapkan sebelumnya. Wawancara tidak terstuktur (Unstructured Interview) adalah wawancara yang tidak berpedoman pada daftar pertanyaan.

\section{III.5.3.3. Analisa Data}

Metode analisis data yang digunakan dalam pemecahan masalah perancangan ini adalah dengan metode $5 \mathrm{~W}+1 \mathrm{H}$ yang akan membahas mengenai spesifikasi perancangan karya.

$>$ What : Perancangan kampanye sosial Save Kendeng

$>$ Where : Indonesia (Media Sosial)

$>$ When : Saat ini dan di masa yang akan dating

$>$ Who : Target sasaran adalah Masyarakat Pengguna Media Sosial

$>$ Why : Karena sudah berdampak pada lingkungan alam yang sangat membahayakan

$>$ How : Dalam hal ini perancang akan membuat iklan layanan masyarakat dalam bentuk poster untuk media sosial.

Melalui hasil analisa data yang didapat peneliti berharap hasil desain kampanye sosial nantinya dapat berpengaruh terhadap perjuangan masyarakat di sekitar pegunungan Kendeng. Selain itu desain yang dirancang dapat berdampak positif bagi desainer-desainer 
DKV yang lain dalam hal membuat kampanye sosial dengan memanfaatkan media-media sosial yang dapat merambah di seluruh pelosok negeri. Hal ini dikarenakan jika hanya menggunakan media-media seperti: spanduk, baliho, poster, dan sejenisnya, hanya akan dilihat serta direspon oleh masyarakat dimana kampanye sosial itu di letakkan.

\section{III.6. Hasil Desain}

Berikut hasil rancangan desain Iklan Layanan Masyarakat yang dirancang
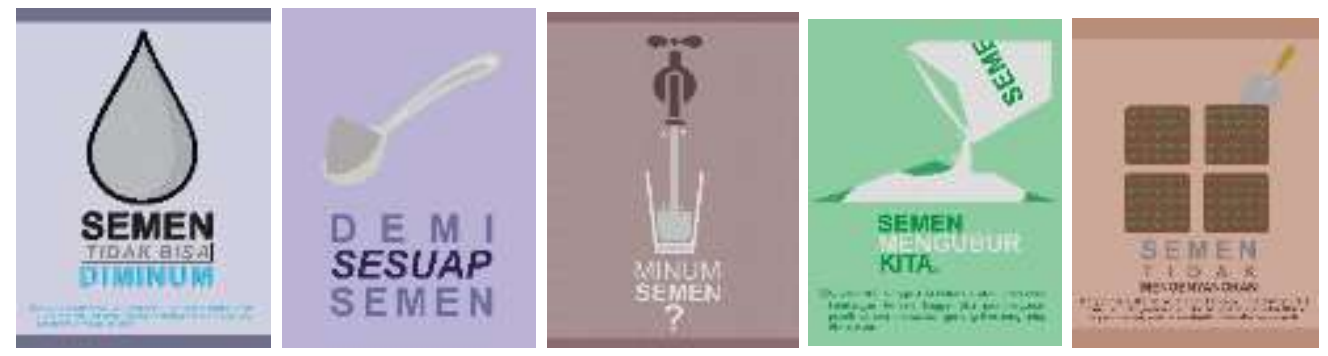

Gambar 5. Hasil ILM yang dirancang dapat diterapkan dalam bentuk Poster Sumber: Sony Sirait, 2015

\section{KESIMPULAN}

Berdasarkan hasil penelitian dengan judul "Perancagan Iklan Layanan Masyarakat Save Kendeng" dapat ditarik kesimpulan bahwa sebuah kampanye sosial dapat dikatakan berhasil jika mendapat respon positif dari orang-orang yang melihatnya. Kampanye sosial SAVE KENDENG yang dirancang dan dipublikasikan melalui media sosial diharapkan dapat mendapat perhatian yang besar dari masyarakat Indonesia dan mendapat tanggapan demi kelangsungan hidup masyarakat yang berada di seitar pegunungan Kendeng. Media sosial dijadikan ujung tombak pada penelitian ini karena media sosial sngat cepat dalam menyebarkan informasi, serta lebih cepat mendapat tanggapan oleh para penggunanya bukan hanya yang ada di Indonesia namun juga berada di luar negeri.

ILM yang dirancang dan dipublikasikan ke media sosial sangat diharapkan dapat membantu menyuarakan hati para masyarakat yang tinggal di sekitar pegunungan Kendeng. Melalui ILM ini juga dapat menggerak hati nurani pemilik usaha pabrik semen juga pemangku kekuasaan negara yang memiliki wewenang dalam menanggulangi permasalahan. Dalam perancangan ILM ini juga diharapkan dapat menggerakan hati nurani para desainer-desainer komunikasi visual yang lain untuk dapat membuat ILM yang lain untuk terus menyuarakan kepentingan-kepentingan sosial.

\section{DAFTAR PUSTAKA}

[1] Cangara, Hafied. (2006). Pengantar Ilmu Komunikasi. Jakarta: PT Raja Grafindo Persada.

[2] Cenadi, C. Suharto. (1999). Elemen-elemen dalam Desain Komunikasi Visual. Jurnal Nirmana Vol. 1, No.1, Januari 1999, hal. 1 -11.

[3] Kusrianto, Adi. (2007). Pengantar Desain Komunikasi Visual. Yogyakarta: Andi Offset. 
[4] Prayitno, Karina Tiffany, et al. (2013). Perancangan ILM Kampanye Pemeriksaan Kesehatan dan Pengobatan Dini. Jurnal DKV Adiwarna Vol. 1, No. 2, hal. 121131.

[5] Pujrianto. (2005). Desain Grafis Komputer (Teaori Grafis Komputer). Yogyakarta: Andi Offset.

[6] Sanyoto, Sadjiman Ebdi. (2005). Nirmana Elemen-elemen Seni dan Desain. Yogyakarta: Jalasutra.

[7] Sarwono, Jonathan dan Hary Lubis.(2007). Metode Riset untuk Desain Komunikasi Visual. Yogyakarta: Andi Offset.

[8] Setyawan, Eka Ari. (2014). Kampanye Sosial Penanggulangan Sampah Plastik di Kabupaten Bekasi Timur. Jurnal Komposisi Vol. 1 No. 2, hal. 1-11.

[9] Sobur, Alex. (2003). Semiotika Komunikasi. Bandung: P.T.Rosdakarya.

[10] Vardiansyah, Dani. (2004). Pengantar Ilmu Komunikasi. Bogor: Ghalia Indonesia.

[11] Widiantoro,Danu. (2015). Strategi Perancangan Poster Pada ILM Kampanye Menabung Air di Yogyakarta. Jurnal Kreatif Vol. 3, No. 1, Mei 2015, hal. 155-164.

[12] Wong, Wucius. (1986). Principle of Form and Design. New York: Von Nostraid Reinhold. 